\title{
Alberta Piping Plover Recovery Plan 2005-2010
}
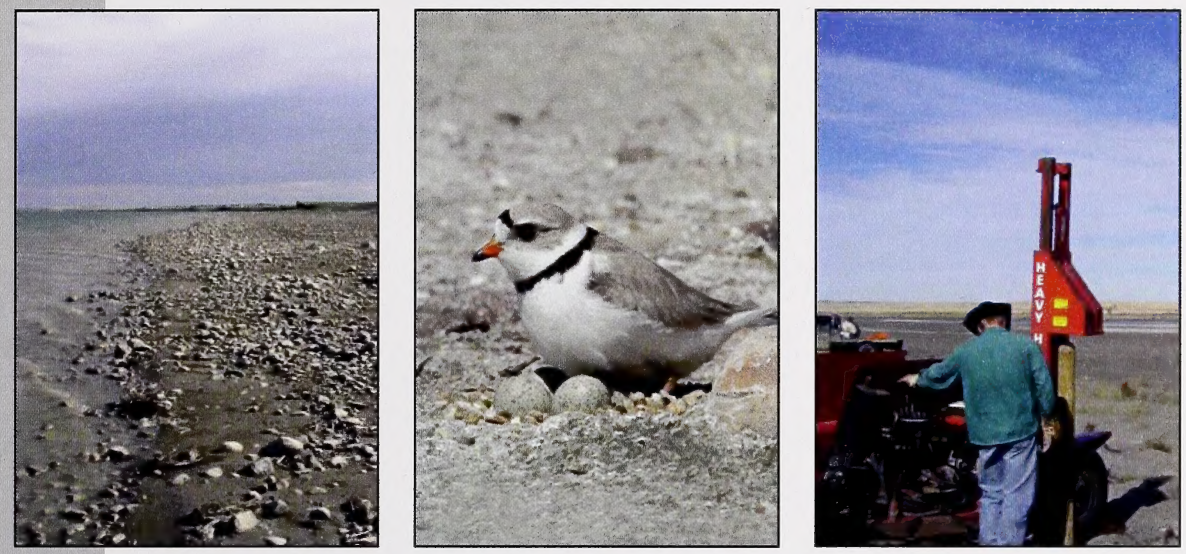

Alberta Species at Risk Recovery Plan No. 10

Alborta 
Digitized by the Internet Archive in 2016

https://archive.org/details/albertapipingplo00pres_2 


\title{
Alberta Piping Plover Recovery Plan 2005-2010
}

\author{
Prepared by:
}

The Alberta Piping Plover Recovery Team

David R. C. Prescott (Team Leader), Alberta Fish and Wildlife Division

Michael Barr, Ducks Unlimited Canada / Alberta North American

Waterfowl Management Plan

Lance C. Engley, Alberta Conservation Association

J. Paul Goossen, Canadian Wildlife Service

Gerald A. Haekel, Alberta Public Lands and Forest Division

D. Edward Hofman, Alberta Fish and Wildlife Division

B. Craig Horner, Alberta Beef Producers

Dug Major, Special Areas Board

Dave Moore, Alberta Fish and Wildlife Division

Tara Worobetz, Nature Conservancy of Canada

\section{June 2006}

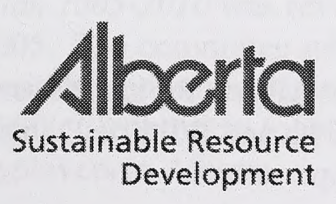


Publication No.: I/239

ISBN: 0-7785-4536-9 (Printed Edition)

ISBN: 0-7785-4537-7 (On-line Edition)

ISSN: $1702-4897$ (Printed Edition)

ISSN：1702-4900 (On-line Edition)

Cover photos: D. Prescott (left), G. Court (middle), D. Sturgess (right)

For copies of this report, contact:

Information Centre - Publications

Alberta Sustainable Resource Development

Main Floor, Great West Life Building

9920 - 108 Street

Edmonton, Alberta, Canada T5K 2M4

Telephone: (780) 422-2079

\section{OR}

Visit the Species at Risk Program web site at:

www.srd.gov.ab.ca/fw/speciesatrisk

This publication may be cited as:

Alberta Piping Plover Recovery Team. 2006. Alberta Piping Plover Recovery Plan, 2005-2010. Alberta Sustainable Resource Development, Fish and Wildlife Division, Alberta Species at Risk Recovery Plan No. 10. Edmonton, AB. 27 pp. 


\section{PREFACE}

Albertans are fortunate to share their province with a diverse variety of wild species. Populations of most species of plants and animals are healthy and secure. However, a small number of species are either naturally rare or are now imperilled because of human activities. Recovery plans establish a basis for cooperation among government and stakeholders to ensure these species and populations are restored or maintained for future generations.

Alberta's commitment to the Accord for the Protection of Species at Risk and to the National Framework for the Conservation of Species at Risk, combined with requirements established under Alberta's Wildlife Act and the federal Species at Risk Act, has resulted in the development of a provincial recovery program. The overall goal of the recovery program is to restore species identified as Threatened or Endangered to viable, naturally self-sustaining populations within Alberta.

Alberta species at risk recovery plans are prepared under the supervision of the Fish and Wildlife Division, Alberta Sustainable Resource Development. These recovery plans are prepared by recovery teams composed of a variety of stakeholders including conservation organizations, industry, landowners, resource users, universities, government agencies and others. Membership is by invitation from the Director of Wildlife Management, and includes representation from the diversity of interests unique to each species and circumstance. Conservation and management of these species continues during preparation of the recovery plan.

Recovery plans include three main sections: background information that highlights the species' biology, population trends and threats; a recovery section that outlines goals, objectives, and strategies to address the threats; and an action plan that profiles priority actions required to maintain or restore the Threatened or Endangered species.

These plans are provided by the recovery team as advice to the Minister of Sustainable Resource Development (the Minister; the Department) and to all Albertans. The Department, other provincial departments, as appropriate, and Alberta's Endangered Species Conservation Committee review draft recovery plans, and provide recommendations to the Minister. In addition, an opportunity for review by the public is provided.

Approved plans are a summary of the Department's commitment to work with involved stakeholders to coordinate and implement conservation actions necessary to restore or maintain these species. Recovery plans are "living" documents and are revised as conditions change or circumstances warrant. Implementation of each recovery plan is subject to the availability of resources, from within and from outside government.

The Alberta Piping Plover Recovery Plan 2005-2010 was reviewed by the Endangered Species Conservation Committee in October 2005. The committee subsequently recommended to the Minister that the plan be approved as written, and implemented. In early 2006, the Minister approved the recovery plan and directed the Department to implement the plan to guide the continued recovery program for piping plovers in Alberta. 
PREFACE

ACKNOWLEDGEMENTS

vi

EXECUTIVE SUMMARY

vii

1.0 INTRODUCTION

1.1 Provincial and Federal Status

1.2 Recovery Team

2.0 SPECIES BIOLOGY

2.1 Breeding Biology

2.2 Habitat 3

2.3 Population Size, Distribution and Trends in Alberta 3

3.0 THREATS AND LIMITING FACTORS

3.1 Predation

3.2 Livestock Grazing 5

3.3 Human Recreation/Disturbance 5

3.4 Vegetation Encroachment 6

3.5 Industrial Development 6

3.6 Water Management Activities___ 6

3.7 Other Factors

4.0 CRITICAL HABITAT

4.1 Identification

4.2 Destruction of Critical Habitat

4.3 Effective Protection of Critical Habitat____ 9

5.0 RESEARCH NEEDS 10

6.0 RECENT RECOVERY AND CONSERVATION EFFORTS __ 10

7.0 RECOVERY STRATEGY ___ 11

7.1 Biological and Technical Feasibility of Recovery ___ 11

7.2 Guiding Principles__ 12

7.3 Recovery Goal__ 13

7.4 Recovery Objectives ___ 13

7.5 Strategies for Recovery ___ 13

8.0 ACTION PLAN__ 14

8.1 Habitat Management and Protection___ 14

8.2 Productivity Enhancement __ 15 
8.3 Information and Outreach 15

8.4 Population Monitoring and Research 15

8.5 Plan Management and Administration 16

8.6 Resource Acquisition 16

9.0 IMPLEMENTATION SCHEDULE AND COSTS 17

10.0 SOCIO-ECONOMIC CONSIDERATIONS 18

11.0 PLAN REVIEW AND AMENDMENT 18

12.0 REFERENCES 19

13.0 APPENDICES 24 


\section{ACKNOWLEDGEMENTS}

The members of the Alberta Piping Plover Recovery Team thank their respective organizations for providing in-kind support for the preparation of this plan. We also thank two former team members, who had substantive input into the management of plovers in Alberta over the past few years, and whose ideas have helped shape the current plan: Tom Sadler (Ducks Unlimited Canada), and Laurel Murphy (Nature Conservancy of Canada). Dan Sturgess and Roy Schmelzeisen (Alberta Conservation Association) were instrumental in the implementation and success of the inaugural recovery plan, and provided valuable input into development of the new plan. We also thank Jake Bureyko (Alberta Public Lands and Forests Division) for providing information on ownership of "critical habitat" areas, and Kelley Kissner (Alberta Fish and Wildlife Division) for assembling much of the background information contained in this document.

Funding from the Species at Risk Program of Alberta Sustainable Resource Development supported the preparation of the Alberta Piping Plover Recovery Plan, 2005-2010. 


\section{EXECUTIVE SUMMARY}

The piping plover (Charadrius melodus) is a small shorebird that breeds on sand or gravel beaches on the Atlantic coast, Great Lakes and Great Plains. Birds spend the winter along the southeastern Atlantic seaboard and the coast of the Gulf of Mexico, including some Caribbean islands. Less than 6000 individuals occur within the North American range, with approximately one-third of these breeding in Canada. The species' range and population size has declined in recent decades, and the piping plover is listed as an Endangered species in most parts of its range, including in Canada under the federal Species at Risk Act (SARA). Reasons for the population decline include increasing levels of predation, and disturbance or habitat deterioration due to agricultural, industrial and recreational use of shorelines.

In Alberta, piping plovers have been reported from at least 85 lakes in the southern half of the province, with breeding being confirmed on 51 lakes. The distribution of populations within the species' range varies annually, and is determined by local water conditions. In any given year, the species occurs on about 20 lakes in the province. During the past five years, the provincial population has numbered around 150 individuals, with the majority occurring in the aspen parkland and northeast boreal regions.

In February 2000, the piping plover was listed as Endangered in Alberta, because of low population size $(<250)$, threats to habitat, and an inability of existing management to increase population levels. Shortly thereafter, the Minister of Sustainable Resource Development initiated recovery actions with the issuance of an Initial Action Statement, and the establishment of a multi-stakeholder recovery team that would advise the Minister on all matters relating to piping plover conservation in the province. This team produced the Alberta Piping Plover Recovery Plan, 2002-2004, which aimed to recover piping plover populations in Alberta through the protection of nests and the conservation of habitat through cooperative initiatives with land users. Implementation of that recovery plan is now complete. Management efforts resulted in a reduction in human impacts on plover habitat, and yielded breeding productivity that met or exceeded the stated target of 1.25 chicks/pair/year. The Alberta Piping Plover Recovery Plan, 2005-2010 represents a continuation of efforts to recover and conserve piping plovers in Alberta.

This recovery plan is guided by the following principles: (1) the recovery of piping plovers in Alberta is both achievable and desirable; (2) a loss of habitat and individuals is unacceptable; (3) a cooperative approach with landowners, industry and other agencies is essential; (4) management actions will employ tools resulting in the most immediate benefit to piping plovers and will be based on the best information available; (5) landowners and leaseholders will not be unduly affected by the costs associated with recovery measures; (6) activities will be restricted to a small number of effective and achievable actions; (7) recovery actions will embrace an ecosystem (holistic) approach to management; (8) predator management activities will be accomplished through passive means; and (9) the recovery process will be guided by the concept of adaptive management.

The recovery goal for Alberta is to achieve a well-distributed, long-term average population of 300 individual piping plovers within their historical range in the province. During implementation of the Alberta Piping Plover Recovery Plan, 2005-2010, the objectives are: 
(1) To minimize anthropogenic impacts on the quantity and quality of piping plover habitat;

(2) To employ all management techniques possible to achieve a median fledging rate of greater than 1.25 chicks/pair/year in the province;

(3) To increase public awareness of piping plovers and their management in Alberta; and

(4) To monitor the progress of past and current management efforts in the province.

The goal and objectives of the recovery plan will be achieved by the implementation of six distinct strategies (habitat management and protection, productivity enhancement, information and outreach, population monitoring and research, plan management and administration, and resource acquisition), which will be pursued concurrently over the five-year period. A series of specific actions in each of these strategic areas is detailed, along with anticipated costs and lead agencies.

Management will occur in all areas of the province where plovers occur, but will be especially focused on areas designated under the federal Species at Risk Act as being "critical habitat" for the recovery of this endangered species. In Alberta, proposed critical habitat areas include the crownowned shorelines of 43 quarter sections of land on 13 lakes (Akasu, Baxter, Birch, "Chain Lake \#4", Dowling, Handhills, Killarney, Little Fish, Muriel, "Piper", Red Deer, Sunken and "West" Reflex). These areas are proposed as critical habitat based on their frequency and magnitude of use by piping plovers over the past 15 years, and on their importance in achieving the provincial recovery goal. Two additional lakes ("Rider" Lake and Rockeling Bay), meet the criteria for designation at the basin level, but there is insufficient information to propose specific quarter sections of shoreline as critical habitat at this time.

The overall cost of the actions detailed in the recovery plan is $\$ 897,000$ over five years, including both cash and essential "in-kind" support. A variety of agencies will be invited to participate in the funding and implementation of recovery initiatives. 


\subsection{INTRODUCTION}

\subsection{Provincial and Federal Status}

In February 2000, the Minister of Sustainable Resource Development approved the up-listing of the piping plover from Threatened to Endangered in Schedule 6 of the Wildlife Regulation under Alberta's Wildlife Act, based on the recommendation from the Endangered Species Conservation Committee (ESCC). The status revision was based on Alberta's very small population (less than 250), persistent threats to habitat, and an inability of recent management actions to increase population levels. The Minister's Initial Action Statement specified that a recovery plan would be prepared within 24 months, that those organizations with a stake in piping plover issues should be invited to participate in recovery planning, and that sufficient new resources should be made available to support essential conservation actions. Furthermore, the action statement advised that government land-use management systems should be strengthened on crown land to prevent the loss of nests, and that management should ensure the protection of nests (and associated habitats) through direct contact with landowner/disposition holders to facilitate voluntary conservation and/or the negotiation of cooperative management strategies. In 2002, the Alberta Piping Plover Recovery Plan, 2002-2004 (Alberta Piping Plover Recovery Team 2002) was developed to embrace the directives of the Initial Action Statement. Implementation of recovery actions outlined in that plan has helped to reduce human impacts on plover habitat and has allowed productivity goals outlined in the plan to be met or exceeded (Alberta Piping Plover Recovery Team 2005). The Alberta Piping Plover Recovery Plan, 2005-2010 represents a continuation and refinement of recovery and conservation efforts for piping plovers in Alberta.

Nationally, the piping plover was listed as Endangered in 2001 due to a small number of breeding pairs in Canada, decreasing population sizes and habitat quality, and low reproductive success (COSEWIC 2005). The species is now listed under the federal Species at Risk Act (SARA). In 2002, the National Recovery Plan for the Piping Plover was published (Goossen et al. 2002) and a National Recovery Strategy for the Piping Plover is nearing completion (Martens and Goossen, in prep). The Alberta Piping Plover Recovery Plan, 2005-2010 is intended to be compliant with SARA and to be compatible with recovery and conservation initiatives outlined in the National Recovery Plan and the National Recovery Strategy.

\subsection{Recovery Team}

The Alberta Piping Plover Recovery Team was initiated by the Minister of Sustainable Resource Development, and receives operational guidance and approval from the Director of Wildlife Management. The team's primary responsibility is to facilitate the conservation and recovery of piping plovers in Alberta, and to provide expert advice to the Minister on the management of this endangered species. The team is also responsible for writing, updating and guiding the implementation of the recovery plan, and for providing input to the Prairie Piping Plover Recovery Team on the management of piping plovers in Alberta. The team does not implement recovery actions directly, although team members and their associated organizations will participate in the recovery initiatives. Because of the multi-stakeholder nature of recovery issues, team membership will remain dynamic and strive for the best representation of affected parties. The team will encourage and facilitate the involvement of all interested parties in the 
recovery of piping plovers in Alberta, whenever possible, and will report annually on the progress of the recovery program.

\subsection{SPECIES BIOLOGY}

\section{$\underline{2.1 \text { Breeding Biology }}$}

The piping plover (Charadrius melodus) is a small, thrush-sized shorebird characterized by its unique dry-sand colouration, high pitched 'piping' call, and habit of breeding on open sand or gravel beaches (Goossen et al. 2002). Three distinct breeding populations are recognized: the Atlantic coast (C.m. melodus), Great Lakes, and Great Plains (C. m. circumcinctus) populations. Birds breeding on the Atlantic coast tend to winter in coastal areas of the southeastern United States (Virginia to Florida), whereas the two inland-breeding populations generally winter from Florida to northern Mexico (Haig 1992). Band returns indicate that many Alberta birds winter near the Texas/Mexico border (Prescott and Engley, in prep). The continental population is fewer than 6000 individuals, with approximately one-third of these breeding in Canada (Plissner and Haig 1997; Ferland and Haig 2002). The population size and range of piping plovers have contracted in North America over the past few decades. The species has disappeared as a breeding bird from Illinois, Indiana, Ohio, Pennsylvania and New Hampshire, and populations have dropped to extremely low levels in Ontario and Iowa (Haig 1992, Goossen et al. 2002).

In Alberta, piping plovers arrive on their breeding grounds in late April (Pinel et al. 1991, Heckbert 1994, Heckbert and Cantelon 1996). Males establish a territory and attract a mate with a combination of aerial and ground displays. Clutches usually contain four eggs (Whyte 1985, Haig 1992). The latest clutch initiation for Alberta is recorded as 6 to 10 July (Alberta Fish and Wildlife Division 1991), but few nests are initiated after mid-June (Prescott and Engley, in prep.). Incubation of eggs is shared by both sexes and lasts 26 to 28 days (Haig 1992). Young leave the nest within several hours of hatching (Haig 1992), and are capable of sustained flight between 18 and 25 days of age (Cairns 1982, Whyte 1985, Prindiville Gaines and Ryan 1988, Murphy et al. 1999). Most birds leave the Canadian prairies for wintering grounds by the first week in August (Wershler and Wallis 1987).

Reproductive success of piping plovers is highly variable among lakes and across years (Goossen 1994, Prescott and Engley, in prep.). Females are capable of breeding at one year of age and will renest if the eggs are destroyed early in the season, but have only been known to produce one brood per year (Haig and Oring 1988a, Bottitta et al. 1997). Estimates of fledging success in Alberta calculated between 2001 and 2004 range from 1.22 to 1.67 young/pair (Prescott and Engley, in prep., Alberta Piping Plover Recovery Team 2005). These values are considerably higher than an earlier estimate of 0.50 young/pair in the province (Richardson 1999). Increased fledging success is largely due to efforts to reduce predation on nests (predator exclosures) and to habitat stewardship by landholders and other stakeholders (Alberta Piping Plover Recovery Team 2005). Various models have estimated that minimum productivity levels of between 1.13-1.7 young/pair are required to maintain stable populations on the Great Plains (Ryan et al. 1993, Plissner and Haig 2000). The most recent model suggests a median productivity of 1.25 chicks/pair/year is required (Larson et al. 2000). 
Estimates of fidelity to breeding areas on the Great Plains range between $42 \%$ and $71 \%$ for adults, but are typically less than $14 \%$ for juveniles (Whyte 1985, Haig and Oring 1988a,b, Goossen 1989, Root et al. 1992). Haig and Oring (1988b) demonstrated that fidelity is highest in areas with large amounts of suitable breeding habitat. Birds have been known to disperse up to $1500 \mathrm{~km}$ from one breeding season to the next (Haig and Oring 1988b). Over $90 \%$ of reencounters with Alberta-banded birds during the breeding season occur within this province (Prescott and Engley, in prep.). This indicates that management initiatives and funds directed at the Alberta plover population directly benefit local birds.

\section{$\underline{2.2 \text { Habitat }}$}

In Alberta, the piping plover generally inhabits shorelines and islands of large alkaline lakes (Prescott 1997). Nesting typically occurs on gravel substrates in areas with relatively wide, sparsely vegetated beaches. The availability of suitable nesting substrates for piping plovers depends on variations in water level on nesting lakes. Periodic high-water events may restrict beach width and temporarily limit the availability of nesting habitat, but eventual recession of water levels exposes gravel deposits which provide unvegetated breeding habitat for several years thereafter. Such variations in water levels are typical in prairie ecosystems. Habitat availability for plovers, and the presence and size of local breeding populations, can therefore differ greatly between years (Prescott 2001a).

\subsection{Population Size, Distribution and Trends in Alberta}

Piping plovers have a widespread but sparse distribution in Alberta. Four major surveys have been conducted in the province. In 1986, 288 plovers were located on 28 water bodies (Wershler and Wallis 1987). In 1991, the first International Piping Plover Census was conducted across North America. In Alberta, 48 water bodies were surveyed and 180 plovers were recorded (Hofman 1994). The next International Census in 1996 included 103 lakes and recorded 276 plovers at 31 sites (Bjorge 1997). During the 2001 International Census, a total of 126 lakes were surveyed and 150 birds were recorded on 23 lakes (Prescott 2001b). Populations on many of the 'traditional' key lakes were much lower than in previous years, despite reasonable habitat conditions (Prescott 2001b). Overall, the provincial population in 2001 had declined by $47.9 \%$ since 1986 , and $45.7 \%$ since 1996 . The magnitude of these declines is undoubtedly underestimated, as survey effort and the skill level of observers has increased with each survey (Prescott 2001b).

Annual surveys of most lakes known to have suitable habitat have been conducted since 2002 . In the first year, 44 lakes were surveyed and 141 plovers were recorded on 19 lakes (Engley and Schmelzeisen 2002). In 2003, 33 lakes were surveyed with 152 plovers occurring on 23 lakes (Schmelzeisen and Engley 2003). In 2004, 38 lakes were surveyed with 134 plovers recorded on 21 lakes (Engley et al. 2004). These data suggest that the provincial population has been relatively stable since the last International Census.

To date, piping plovers have occurred on at least 85 lakes in the province (Appendix 1 and 2). Although new waterbodies with plovers continue to be found, it is assumed that most basins 
suitable for plovers have been identified. To date, breeding has been confirmed on 51 of these lakes (Appendix 1). However, changing habitat conditions mean that not all lakes will support breeding pairs in any given year. The Alberta piping plover population has tended to shift northwards in the past decade as basins in the grassland region of Alberta have been impacted by drought (Prescott and Engley, in prep.). Since the early 2000s, most piping plovers in Alberta have been found on saline lakes across the Central Parkland Subregion, and in the adjacent parts of the Dry Mixedwood Subregion to the north, and the Northern Fescue Subregion to the south (Prescott 2001b, Engley and Schmelzeisen 2002, Schmelzeisen and Engley 2003, Engley et al. 2004; see Achuff 1994 for a description of Natural Regions and Subregions in Alberta).

\subsection{THREATS AND LIMITING FACTORS}

Limiting factors are considered to be those conditions that degrade habitat suitability, reduce survivorship of young or adults, or decrease nesting success of adults once they are established at a site (Prescott 1997). From a management standpoint, an understanding of these factors is important because they identify mechanisms through which plover recovery may be achieved. The limiting factors discussed below have been identified as affecting populations of piping plovers in Alberta (Wershler 1992, Prescott 1997, Goossen et al. 2002, Westworth et al. 2004). Management actions that have been used to mitigate some of these factors are also listed. However, not all actions may be applicable or practical for piping plover recovery in Alberta.

\subsection{Predation}

Predation on eggs and chicks is the greatest source of reproductive failure in piping plovers on the Great Plains. Richardson (1999) found that $64 \%$ of nesting attempts in Alberta failed because of depredation. Recent analysis suggests that since 1994, the probability that an unprotected plover nest in Alberta will hatch is only 29\% (Engley and Prescott 2004, Prescott and Engley, in prep.). This value is apparently lower that anywhere else in North America. Instances of predation are rarely observed, and the types of predators are poorly documented (Haig et al. 1988). American crows (Heckbert 1994) and gulls (Heckbert and Cantelon 1996) are most often implicated in Alberta. However, black-billed magpies, common grackles, blackbirds, American ravens, great horned owls, northern harriers, merlins, ground squirrels, striped skunks, mink, red fox, coyotes, raccoons, weasels, white-tailed deer and domestic dogs have also been observed, or suspected of, preying upon eggs or young in central North America (Whyte 1985, Espie et al. 1992, Murphy et al. 2003, Ivan and Murphy 2005).

Although the loss of eggs and chicks to predators is a natural process, there is evidence that urbanization and recreational use of beaches have increased populations of gulls, foxes and skunks in some areas (Haig 1985). Little is known about adult mortality. However, mink, red fox, peregrine falcons, red-tailed hawks and great horned owls and merlins are known to be responsible for adult predation (Haig 1992, Michaud and Prescott 1999, Murphy et al. 2003). Management tools available to decrease predation of nests and/or adults include predator removal, destruction of stick nests during the nonbreeding season, erection of electric fencing and the use of predator exclosures around nests (Schmelzeisen et al. 2004). A predator exclosure project initiated in Alberta in 1996 showed that fledging success rates of exclosed nests were 
more than double those of unprotected nests (Richardson 1999). More recent efforts to reduce predation on nests have been at least as successful. Nest success during implementation of the inaugural recovery plan (2002-2004) ranged from $87-98 \%$ for exclosed nests, and $43-55 \%$ for unexclosed nests (Engley and Schmelzeisen 2002, Engley et al. 2004, Schmelzeisen and Engley 2003).

\subsection{Livestock Grazing}

Livestock can disturb nesting substrates, interfere with normal nesting behaviour by established birds, and directly destroy eggs. In addition, young plovers may fall into deep hoof prints and be unable to escape (Wershler and Wallis 1987, Hofman 1992). Furthermore, the construction of dugouts adjacent to shorelines can foul nesting beaches, change basin hydrology, and accelerate vegetative encroachment (Heckbert 1994). Studies have shown nesting success to be lower on territories with evidence of cattle activity (Prindiville Gaines and Ryan 1988, Hofman 1992). It should be noted, however, that grazing reduces vegetation on shorelines. Controlled grazing has recently been used to slow the rate of vegetation encroachment and thereby improve habitat quality on Little Fish Lake in southern Alberta (Alberta Piping Plover Recovery Team 2005).

During the 2001 International Piping Plover Census, grazing was assessed to be a potential threat on $66.3 \%$ of all lakes surveyed and on $69.6 \%$ of lakes containing plovers in Alberta (Prescott $2001 \mathrm{~b})$. These numbers are relatively consistent with those reported in 1991 (66.7\%; recalculated from Hofman 1994) and 1996 (82.6\%; Bjorge and Murphy 2004). Despite the potentially negative effects of livestock on plover populations, impacts can be reduced by effective and inexpensive measures such as fencing, establishment of new water sources, and deferred grazing practices. Increased stakeholder awareness and habitat stewardship conducted since 2002 have greatly reduced the threat of grazing on the Alberta population (Alberta Piping Plover Recovery Team 2005).

\subsection{Human Recreation/Disturbance}

Motorized off-road travel (all-terrain vehicles), or non-motorized, recreational use of beaches can affect plovers by directly destroying nests and eggs, or by interfering with territory establishment and other reproductive behaviours (Cairns 1982, Flemming et al. 1988, Haig et al. 1988). During the 2001 International Piping Plover Census, motorized vehicles were a threat on $18.6 \%$ of all lakes surveyed in Alberta, and on $34.8 \%$ of lakes supporting piping plovers. Similarly, recreational/residential use was determined to have an impact on $12.8 \%$ of lakes surveyed and $26.1 \%$ of lakes supporting plovers (Prescott 2001b). Since the late 1990s, the two lakes with the greatest populations of piping plover in Alberta also have cottage developments ("West" Reflex, and especially Muriel Lake). Management activities aimed at reducing human disturbance typically include the erection of cautionary and interpretive signage, and contact with recreation and user groups to increase awareness of plovers and their conservation requirements. However, restrictions on shoreline use are occasionally necessary, such as at Muriel Lake where a seasonal wildlife sanctuary was created in 2003 to prevent disturbance to plovers (Alberta Piping Plover Recovery Team 2005). 


\section{$\underline{3.4 \text { Vegetation Encroachment }}$}

The creation of suitable nesting habitat for piping plovers requires alternating periods of high and low water to remove vegetation and expose gravel substrates on nesting beaches (Prescott 1997). As water recedes, vegetation slowly invades the substrates until habitat becomes unsuitable for nesting, unless the beach is rejuvenated by high-water events. Although such encroachment is a natural occurrence, anthropogenic influences (i.e., grazing and water management) can affect the rate and extent of plant growth. Of particular concern is the stabilization of water bodies to improve recreational opportunities for humans. Such projects greatly diminish the probability of high-water events, and thereby reduce long-term habitat suitability for plovers. One example of this in Alberta is at Buffalo Lake, where stabilization in the 1990s has resulted in the loss of habitat quality at the adjacent "Rider" Lake and Rockeling Bay, which supported significant plover populations in the 1980s and early 1990s (Goossen et al. 2000). Stabilization projects have been also proposed for other plover lakes in Alberta (e.g., Little Fish Lake [Goossen 1994]).

Management tools used to minimize vegetation encroachment include burning, herbicide use, mechanical ground disturbance and fall/winter grazing. Burning was attempted at Rockeling Bay in the mid-1990s with limited success. Mechanical clearing of vegetation has been recently employed at Red Deer Lake, and fall grazing is currently being used to manage habitat at Little Fish Lake (Alberta Piping Plover Recovery Team 2005). These techniques have modestly improved habitat for plovers, but cannot fully reverse the normal progression of vegetation encroachment on shorelines.

\section{$\underline{3.5 \text { Industrial Development }}$}

Industrial activities (primarily oil and gas exploration and extraction) around plover breeding sites could pollute water and shorelines, deplete water levels or interfere with ground water dynamics, and eliminate surrounding vegetation (Wershler 1992). The direct impacts of oil and gas development on plover habitat are not well documented, but activity has been reported in close proximity to several breeding sites in Alberta. During the 2001 International Piping Plover Census, industrial activity, including petroleum exploration/extraction, was assessed to be a potential threat on $10.5 \%$ of all lakes surveyed and on $13.0 \%$ of lakes supporting plovers in Alberta (Prescott 2001b). The primary means of reducing the effects of industrial development include the placement of protective notations (PNTs) on public lands to alert developers to the presence of an endangered species, and the application of timing and setback restrictions (Alberta Fish and Wildlife Division 2001) that minimize disturbance to breeding birds and their habitat. To date, protective notations have been placed on the beds and shores of 12 waterbodies in Alberta. In addition, the referral system has proven successful in obtaining support from industrial operators to limit impacts of development on plover habitat (Alberta Piping Plover Recovery Team 2005).

\subsection{Water Management Activities}

Projects that stabilize water levels to enhance recreational opportunities can remove the natural fluctuation of water levels required to provide plover nesting habitat (see above). However, 
water levels on most large water empoundments are not static, and seasonal changes in water levels create suitable nesting substrates for piping plovers. Typically, water rises in the spring as snow melts, and then falls throughout the summer as irrigation and hydroelectric demands are met. If suitable habitat is exposed when plovers are establishing territories (early May), subsequent rising water can destroy nests and reduce or eliminate habitat necessary for brood rearing (Espie et al. 1992, Jung et al. 1998). In Alberta, water level fluctuations due to irrigation practices are known to have affected plovers breeding on Keho Lake (Wershler 1992).

Fortunately, the use of reservoirs by piping plovers is quite low in this province (Prescott 2001b), but high nest losses often occur on reservoirs in Saskatchewan and in the United States (Goossen et al. 2002). In 2001, water management activities were identified as potential threats on $8.1 \%$ of Alberta lakes surveyed for the International Piping Plover Census and on $8.7 \%$ of lakes supporting plovers (Prescott 2001b).

\section{$\underline{3.7 \text { Other Factors }}$}

A variety of other factors can affect piping plover populations. Many of these factors, however, are either unpredictable or impossible to control or mitigate. For example, severe storms may cause nest losses and reduce fledging success (Murphy et al. 1995, Michaud and Prescott 1999). In addition, because piping plovers spend only $30 \%$ of their annual cycle on the breeding grounds, most adult bird mortalities likely occur in wintering areas or during migration (Root et al. 1992). Events occurring outside of Alberta therefore have the potential for major impacts on local piping plover populations.

The cumulative impact of several independent limiting factors may pose an additional threat to piping plover populations. Thus, even when the independent negative effect of any one factor is assumed to be small, it may still pose a significant threat to the population in combination with other factors. The cumulative impact of several factors may greatly reduce the quality of habitat for piping plovers. In reference to the Alberta population, Prescott (2004) suggests "There is probably sufficient structural habitat to maintain the population, but the quality of this habitat is slowly deteriorating due to increasing predators and a variety of anthropogenic disturbances".

\subsection{CRITICAL HABITAT}

\subsection{Identification}

Critical habitat is defined as "the habitat that is necessary for the survival or recovery of a listed wildlife species" (Species at Risk Act, Section 2). The Alberta Piping Plover Recovery Team recognizes that all habitat for plovers in Alberta is worthy of management and protection. However, the team also recognizes that a particular subset of sites in the province is particularly important for protection, due to the frequency and magnitude of use by plovers, and its contribution towards the achievement of provincial management objectives. Based on minimum criteria outlined in the National Recovery Strategy for the Piping Plover (Martens and Goossen, in prep.) the following criteria will be used to define lakes that contain critical habitat in Alberta:

1) A floating window of 15 years (starting in 1991) to determine site status; 
2) A minimum of five years of survey data within the 15-year window;

3) Average number of plovers over all surveys on a lake being $\geq 4$ adults.

Based on survey information collected from 1991 through 2004, 15 lakes meet these criteria in Alberta: Akasu, Baxter, Birch, "Chain Lake \#4", Dowling, Handhills, Killarney, Little Fish, Muriel, "Piper", Red Deer, "Rider", Rockeling Bay, Sunken and "West" Reflex (see Appendix 1 and 2 for locations). Based on the maximum population sizes recorded on these lakes (Appendix 2 ), the 15 waterbodies proposed for designation have the collective potential to support 464 piping plovers, which is $56 \%$ higher than the provincial recovery goal of 300 adults (see Section 7.3).

Because of the specific habitat requirements of plovers (see Section 2.2), not all of the shoreline on these identified lakes will be considered to be critical for the recovery of the species. The following criteria will be used to identify specific segments of critical habitat on the 15 lakes:

1) Use of shoreline by $\geq 2$ pairs of birds ( $\geq 4$ adults or $\geq 2$ nests) in $\geq 2$ breeding seasons over a 15 -year window; or

2) Any documented use (probable or confirmed breeding) in $\geq 4$ seasons during the 15 -year period.

In all cases, the particular segment of critical habitat on identified lakes will be defined on a quarter-section level, and will extend from the waterline to the normal high water mark.

Based on 1991-2004 survey data, 43 quarter sections on 13 of the 15 critical lakes meet these criteria (Appendix 3). No specific quarter sections met the criteria on either "Rider" Lake or Rockeling Bay. Piping plovers have been virtually absent from these two basins since the mid1990 s, and earlier surveys did not report the specific locations of occupied shorelines.

Information required to delineate specific segments of critical habitat will become available if or when populations return to these lakes. However, it should be noted that the stabilization of adjacent Buffalo Lake may have altered the hydrology of these areas such that their former suitability for breeding piping plovers may be reduced.

Analysis of land titles data shows that the shoreline of all 43 identified quarter sections is classified as bed and shore, and is therefore under ownership of the provincial crown (Appendix 3 ). Many of these quarter sections (20/43) are adjacent to uplands that are wholly or partially under private ownership (Appendix 3). To maintain the anonymity of cooperating and/or adjacent landowners, and to minimize potential human disturbance to these important plover breeding sites, the critical habitat segments are not specifically identified in this report. Rather, designated quarter sections on each lake are generically identified by a letter code (see Appendix $3)$.

Because plover habitat is dynamic, populations shift between lakes and between sites within lakes on an annual basis. For this reason, the list of lakes and sites within lakes that meet the criteria for listing as critical habitat will be reviewed every five years on a prairie-wide basis (Martens and Goossen, in prep.). 


\subsection{Destruction of Critical Habitat}

The Species at Risk Act stipulates that critical habitat for a listed species must be "effectively protected" against destruction. In the case of the piping plover, destruction is defined as "the direct, indirect, or cumulative loss of critical habitat structure or complete loss of function that temporarily or permanently prevents its use by the piping plover for its former function" (Martens and Goossen, in prep.). A number of activities could cause destruction of critical habitat. These activities include, but are not limited to, agricultural activities (tillage, unregulated use of shorelines by cattle), resource extraction (gravel mining, oil and gas development), civil infrastructure (construction of roads, bridges or marinas), radical alterations to normal hydrological regimes (wetland drainage, construction of dams), pollution of water or shorelines, or excessive recreational use (all-terrain vehicles)(Martens and Goossen, in prep.).

Most piping plover habitat in Alberta occurs in relatively unpopulated locations, and is of limited value for anthropogenic purposes. Therefore, the destruction of piping plover habitat would be a rare event in this province, and management activities will normally be focused on maintaining a high quality of habitat rather than preventing destruction. Nevertheless, the potential destruction of any plover habitat, whether it is designated as critical or not, must be vigorously opposed if recovery objectives are to be achieved. The Alberta Piping Plover Recovery Team believes that where due diligence fails, the intentional (as opposed to accidental) destruction of critical habitat that causes a loss of suitability for piping plovers for at least one breeding season should be addressed through compliance measures.

\subsection{Effective Protection of Critical Habitat}

Once critical habitat for piping plovers has been designated in an approved strategy or action plan under $S A R A$, it is the province's responsibility to "effectively protect" it from destruction. There are three methods of critical habitat protection on non-federal land (no plover habitat is known to occur on federal lands in Alberta): (1) existing provincial laws, (2) stewardship agreements drafted according to a national standard, and (3) order from (federal) cabinet (Martens and Goossen, in prep.). Because all critical habitat for piping plovers in Alberta occurs on crown-owned bed and shore, effective protection of these areas is already afforded under Alberta's Public Lands Act. Of particular importance is Section 54(1)(e), which states that:

"No person shall cause, permit or suffer the disturbance of any public land in any manner that results or is likely to result in injury to the bed and shore of any river, stream, watercourse, lake or other body of water or land in the vicinity of that public land".

Alberta's Wildlife Act also offers protection for piping plover habitat through prohibitions on the destruction of nests, and through the establishment of the Muriel Lake Waterbird Sanctuary. This seasonal sanctuary, which prohibits human access between 1 May and 15 August, was established in 2002 to protect key piping plover nesting areas on the lake that are now considered to be critical habitat. 
In practice, the protection of shorelines against damage or destruction must take into account the tenure and use of adjacent uplands. The majority of uplands (23/43) in the quarter sections designated as critical habitat for piping plovers are crown land, but some of these lands are under grazing lease agreements or other dispositions. Furthermore, some uplands are entirely (8/43) or partly (12/43) under private ownership (Appendix 3). Private land users generally have right of access to adjacent shoreline habitat under the Public Lands Act. Accordingly, maintaining high quality habitat for piping plovers will require stewardship by landowners and lease holders. Cooperative management agreements have been very successful in Alberta over the past several years (Alberta Piping Plover Recovery Team 2005), and will continue to be used in all areas (critical or otherwise) where plovers occur in the province.

In addition to the Wildlife Act, Public Lands Act and cooperative stewardship with landowners and leasees, there are other policies, procedures and management activities in Alberta that will minimize the likelihood that habitat for piping plovers will be destroyed or damaged in the province. These include the use of protective notations that alert industrial developers and other parties to the presence of piping plover habitat, established timing and setback guidelines for developments and other activities around plover habitat (Alberta Fish and Wildlife Division 2001), and information and extension activities directed toward beach users to minimize disturbance (e.g., brochures, cautionary and interpretive signage, presentations; see Section 6.0 and Alberta Piping Plover Recovery Team [2005] for additional details).

\subsection{RESEARCH NEEDS}

The biology and ecology of piping plovers are relatively well understood, and research to further document general species biology is not required. Research efforts contributing to recovery and conservation of piping plovers in Alberta should focus on continuation of population and habitat monitoring to assess whether recovery goals are being met. This will include the development of a standardized system of ranking piping plover habitat quality and threats in order to prioritize and quantitatively assess the effectiveness of management activities. Research will also be directed towards identifying predators of piping plover nests, so that the design and deployment of nest exclosures and other productivity enhancement tools can be improved. Many activities undertaken during implementation of this plan will include some measure of data collection, analysis and interpretation, in order to consistently improve existing management techniques.

\subsection{RECENT RECOVERY AND CONSERVATION EFFORTS}

The Alberta Piping Plover Recovery Plan, 2002-2004 outlined recovery strategies and actions necessary for the recovery and conservation of piping plovers in Alberta. All recovery actions outlined in the plan were implemented (see Alberta Piping Plover Recovery Team 2005). Key initiatives included:

- Review and documentation of historical habitat use by piping plovers in the province on a lake and quarter-section basis 
- Application to Alberta Public Lands and Forests Division and the Special Areas Management System for protective notations on 135 quarter sections of crown land where plovers are known to have occurred

- Involvement in numerous referrals concerning industrial development around plover breeding lakes

- Completion of management plans for plovers on 30 lakes in the province

- Personal contact with at least 74 landowners and 260 cottagers on 26 plover-inhabited lakes

- Completion of 15 habitat-improvement projects on 11 lakes. In total 16 lakes were included in habitat improvement or interpretive projects over three years

- Establishment of a seasonal sanctuary to prevent disturbance of plovers on Muriel Lake

- Widespread use of predator exclosures to more than double the hatching success of plover nests

- Completion of a review of predator management techniques applicable to plovers in Alberta

- Numerous presentations to technical and non-technical audiences on plovers and their management

- Preparation and distribution of a landowner information package

- Completion of breeding pair and brood surveys on between 33 and 44 lakes each year, including discovery of new populations on five Alberta lakes

- Banding of over 300 chicks, and compilation of re-encounters with birds on the breeding grounds and on wintering areas along the Gulf of Mexico

- Compilation of plover productivity data gathered since 1994. Analysis showed that the production target of 1.25 chicks/pair/year was exceeded during all three years of plan implementation

- Securement of $\$ 597,500$ in cash funding and in-kind support from numerous individuals and agencies. This total slightly exceeded budgeted funding of $\$ 586,000$.

Most importantly, these activities resulted in two of the three recovery goals outlined in the plan being met or exceeded. Specifically, these activities protected plover habitat quality and quantity from impacts of human activities, and resulted in fledging success rates exceeding 1.25 chicks/pair/year between 2002 and 2004. However, the main goal of the recovery program - the attainment of a well-distributed, long-term average population of 300 individual piping plovers within their Alberta range - has yet to be achieved. This goal is seen as a long-term target of the recovery program, and will require continued work to be realized, and ongoing management to be maintained (Alberta Piping Plover Recovery Team 2005).

\subsection{RECOVERY STRATEGY}

\subsection{Biological and Technical Feasibility of Recovery}

Under the federal Species at Risk Act, species are considered to be recoverable if all of the following criteria apply (Anonymous 2005): (1) individuals capable of reproduction are available; (2) sufficient habitat is present to support the population, or such habitat could be 
made available through management or restoration; (3) threats to the species can be alleviated or mitigated; and (4) the necessary recovery techniques exist and are demonstrated to be effective.

The Alberta Piping Plover Recovery Team believes that all of the conditions necessary for recovery to be feasible are met. The plover population in Alberta appears to have sufficient habitat in which to breed, although it is possible that the quality of this habitat has deteriorated in recent decades due to increased predator populations, recreational use of shorelines, drought, and other threats (Prescott 2004). As a result, natural production is likely lower than is required to sustain the population. However, recent management efforts in Alberta have improved habitat quality in many areas, and have secured the long-term availability of high-quality habitat through the establishment of sanctuaries, the execution of cooperative stewardship agreements with landowners and leasees, and through education and extension activities. In addition, the protection of nests with predator exclosures has vastly improved nesting success to the point where productivity goals have been met or exceeded, and population recovery is theoretically probable (Alberta Piping Plover Recovery Team 2005). These successes have occurred with relatively modest amounts of funding, at levels that should be sustainable in the future. Increased awareness and support for recovery efforts for the piping plover in Alberta also prompts optimism about the probability of population recovery in Alberta.

It is important to acknowledge that there are a number of factors affecting recovery that are beyond the control of the Alberta Piping Plover Recovery Team or this recovery plan. For example, the piping plover's migratory nature and international life cycle requirements mean that the policies and actions of numerous governments and industries will affect the success of recovery efforts in Alberta. The effects of drought on habitat availability, and predator densities also cannot be controlled. For these reasons, it is expected that plovers will require long-term management in the province to ensure that the recovery goal is met and that the Alberta population remains viable. Fortunately, emigration of plovers from Alberta is relatively low and thus, conservation efforts and funding directed at recovery and conservation of plovers in Alberta directly affect the Alberta population.

\section{$\underline{7.2 \text { Guiding Principles }}$}

The recovery and management of piping plovers in Alberta will be guided by the following principles:

- Recovery of the piping plover is both possible and desirable

- The loss of habitat and individuals is unacceptable

- A cooperative approach with landowners, industry and other agencies is essential. This includes shared stewardship, compatible land use and local commitment to management initiatives

- Management actions will employ tools resulting in the most immediate benefit to piping plovers, and will be based on the best information available. However, implementation will not be delayed because of a lack of specific supporting information

- Landowners and leaseholders will not be unduly affected by the costs associated with maintaining or enhancing piping plover habitat, or other recovery measures 
- Activities will be restricted to a small number of effective and achievable actions

- Recovery actions will embrace an ecosystem (holistic) approach to management

- Predator management activities will be accomplished through passive means (deterrence)

- The recovery process will be guided by the concept of adaptive management, whereby recovery actions are evaluated and are revisited, as necessary, to ultimately improve the outcome.

\section{$\underline{7.3 \text { Recovery Goal }}$}

The Alberta recovery goal is to achieve a well-distributed, long-term average population of 300 individual piping plovers within their historical range in Alberta. This goal is consistent with the National Recovery Plan for the Piping Plover (Goossen et al. 2002), the National Recovery Strategy for the Piping Plover (Martens and Goossen in prep.), and the directives of the Minister's Initial Conservation Action Statement.

\subsection{Recovery Objectives}

The recovery goal will be achieved by meeting several objectives:

1) To minimize anthropogenic impacts on the quantity and quality of piping plover habitat

2) To employ all management techniques possible to achieve a median fledging rate of greater than 1.25 chicks/pair/year in the province

3) To increase public awareness of piping plovers and their management in Alberta, and

4) To monitor the progress of past and current management efforts in the province.

\subsection{Strategies for Recovery}

The goal and objectives of the Alberta Piping Plover Recovery Plan 2005-2010 will be achieved through the implementation of six distinct strategies, which will be pursued concurrently over the five-year period. Whenever possible, these strategies and their associated actions will be integrated with those of other species at risk recovery efforts in the province, and with management efforts for piping plovers in other jurisdictions in Canada and the United States. These strategies are:

Habitat Management and Protection - All actions related to assessing and improving the quality and security of breeding habitat for piping plovers in Alberta. Particular emphasis will be placed on the management/protection of sites that meet the criteria of "critical habitat" in Alberta (see Section 4.0). Existing legislation, tools, policies and processes that are applicable to the protection of habitat in Alberta will be used whenever possible.

Productivity Enhancement - All activities related to reducing depredation of piping plover eggs, chicks and adults. The prevention of nest loss will be the major activity under this strategy, because simple and measurably effective tools have been developed to counteract high rates of nest depredation in Alberta. 
Information and Outreach - All actions related to providing information and extension to landowners/leaseholders, industrial interests, recovery partners, and the general public about the conservation and management of piping plovers in Alberta. The focus will be on preventing the degradation or loss of habitat, expanding awareness of conservation issues related to piping plovers, ensuring that stakeholders are informed of local recovery initiatives and results of these initiatives, and gaining support and participation in management activities.

Population Monitoring and Research - All activities relating to the monitoring of population size and distribution, breeding success, and habitat threats and condition for piping plovers in Alberta. These efforts are required in order that management can be effectively applied where and when it is most needed.

Plan Management and Administration - All activities related to the operation of the Alberta Piping Plover Recovery Team, and implementation of the Alberta Piping Plover Recovery Plan. A key element of this strategy is to build linkages with other provincial, national and international initiatives that will benefit piping plover conservation in Alberta.

Resource Acquisition - All actions related to securing funding and other resources needed to support management actions detailed in this plan.

\subsection{ACTION PLAN}

The recovery actions outlined below form the basis of a five-year plan aimed at achieving the recovery goal for Alberta.

\section{$\underline{8.1 \text { Habitat Management and Protection }}$}

1. Identify ownership (public or private) of all newly discovered plover sites on an annual basis. If land is publicly owned, an application for a protective notation will be submitted to Alberta Public Lands and Forests Division or the Special Areas Board. If land is privately owned, the landowner will be contacted regarding plovers and their management.

2. Maintain the recovery team leader as the key contact in the industrial referral system for consultation regarding industrial activities that affect habitat of plover-inhabited lakes.

3. Continually seek opportunities for, and negotiate cooperative agreements with landowners/leaseholders to mitigate threats to plover habitat.

4. Implement habitat-improvement actions specified in cooperative agreements, with the lead organization to be determined on a case-by-case basis.

5. Annually assess habitat quality, threats, and management opportunities on all plover-occupied lakes, with a focus on areas designated under the Species at Risk Act as being "critical habitat". 
6. Annually assess habitat quality and threats on all areas where past management activities have been undertaken, to assess effectiveness of management activities.

\section{$\underline{8.2 \text { Productivity Enhancement }}$}

1. Annually implement the predator exclosure project on as many lakes as available personnel and funding will allow.

2. Employ and expand, were possible, the use of specific predator deterrence measures recommended by Schmelzeisen et al. (2004) to increase plover productivity and survivorship.

3. Produce and distribute an annual report on productivity enhancement activities to funders, stakeholders and other interested parties.

\section{$\underline{8.3 \text { Information and Outreach }}$}

1. Provide information on plover-related issues to technical and non-technical audiences through presentations, signage, and other media.

2. Maintain annual contact with all landowners, cottagers, industry, and other landusers that have cooperated in piping plover management.

3. Produce and distribute an annual newsletter for cooperators, funding partners, and other individuals and agencies.

\subsection{Population Monitoring and Research}

1. Conduct annual adult and brood surveys on a core of at least 25 lakes each year depending on water cycles and habitat availability. All lakes listed as "critical habitat" under the Species at Risk Act will be visited.

2. Coordinate and participate in the 2006 International Piping Plover Census.

3. Conduct an aerial inventory of piping plover habitat in Alberta in the spring of 2006 in order to guide efforts during the International Census. Aerial inventories should be conducted during other years when water conditions show substantial change.

4. Develop an objective system of rating habitat quality and threats in order to determine priorities for management, and to monitor effectiveness of management actions already implemented.

5. Identify, through remote digital imagery, specific predators of piping plover nests and young in order to improve management techniques used to enhance productivity. 
6. Continue with opportunistic banding, capture of banded adults, and compilation of observations of banded birds.

7. Cooperate with any provincial, national, and international initiatives that will provide information to better manage piping plovers in Alberta.

\section{$\underline{\text { 8.5 Plan Management and Administration }}$}

1. Convene the Alberta Piping Plover Recovery Team a minimum of once annually and circulate results of these meetings to interested persons.

2. Monitor and assess the progress of recovery plan actions, and develop new recovery strategies and actions when needed.

3. Liaise with the Prairie Piping Plover Recovery Team and other provincial, multi-provincial, or international conservation initiatives and municipal governments to ensure continuity and flow of information between agencies.

4. Enter accumulated plover data into the Fisheries and Wildlife Management Information System (FWMIS) and other centralized databases following each field season.

5. Prepare and distribute an annual report on recovery plan activities.

\section{$\underline{8.6 \text { Resource Acquisition }}$}

1. Approach government, non-government, and industry partners to participate in or fund piping plover recovery initiatives.

2. Hire and train seasonal staff to participate in annual field programs, and provide training/orientation to staff of cooperating agencies (government and non-government) when opportunities arise. 


\subsection{IMPLEMENTATION SCHEDULE AND COSTS}

The following table provides a timeline and estimated costs (including direct and "in-kind") for implementation of activities detailed in Section 8.0. It is anticipated that a variety of agencies will participate in the funding and implementation of these activities. Costs are not provided for activities that are part of the daily operations of the identified organizations $(*)$.

\begin{tabular}{|c|c|c|c|c|c|c|c|c|}
\hline $\begin{array}{l}\text { Recovery } \\
\text { Plan }\end{array}$ & Action & Lead & \multicolumn{5}{|c|}{ Cost (thousands/year) } & \multirow[t]{2}{*}{ Total } \\
\hline & & & $2005-06$ & 2006-07 & 2007-08 & 2008-09 & $2009-10$ & \\
\hline 8.1 & $\begin{array}{l}\text { Habitat Management \& } \\
\text { Protection }\end{array}$ & & & & & & & \\
\hline 1. & Notations/landowner contact & 1,2 & 3 & 3 & 3 & 3 & 3 & 15 \\
\hline 2. & Liaison in industrial referral system & 1 & * & $*$ & * & * & * & $*$ \\
\hline 3. & Cooperative agreements & 2 & 10 & 10 & 10 & 10 & 10 & 50 \\
\hline 4. & Implement habitat improvement & 1,2 & 50 & 50 & 50 & 50 & 50 & 250 \\
\hline 5. & Monitor critical habitat & 1,2 & 3 & 3 & 3 & 3 & 3 & 15 \\
\hline \multirow[t]{2}{*}{6.} & \multirow[t]{2}{*}{ Monitor managed habitat } & \multirow[t]{2}{*}{1,2} & 3 & 3 & 3 & 3 & 3 & 15 \\
\hline & & & 69 & 69 & 69 & 69 & 69 & 345 \\
\hline 8.2 & Productivity Enhancement & & & & & & & \\
\hline 1. & Predator exclosure project & 2 & 40 & 40 & 40 & 40 & 40 & 200 \\
\hline 2. & Predator deterrent measures & 2 & 2 & 2 & 2 & 2 & 2 & 10 \\
\hline \multirow[t]{2}{*}{3.} & \multirow{2}{*}{ Annual report } & \multirow[t]{2}{*}{1} & 2 & 2 & 2 & 2 & 2 & 10 \\
\hline & & & 44 & 44 & 44 & 44 & 44 & 220 \\
\hline 8.3 & Information \& Outreach & & & & & & & \\
\hline 1. & Presentations & 1,2 & * & $*$ & * & $*$ & * & * \\
\hline 2. & Contact with cooperators & 2 & 3 & 3 & 3 & 3 & 3 & 15 \\
\hline \multirow[t]{2}{*}{3.} & \multirow[t]{2}{*}{ Annual newsletter } & \multirow[t]{2}{*}{1} & 2 & 2 & 2 & 2 & 2 & 10 \\
\hline & & & 5 & 5 & 5 & 5 & 5 & 25 \\
\hline 8.4 & $\begin{array}{l}\text { Population Monitoring \& } \\
\text { Research }\end{array}$ & & & & & & & \\
\hline 1. & Population monitoring & 1,2 & 25 & 25 & 25 & 25 & 25 & 125 \\
\hline 2. & International Census & 1 & 0 & 10 & & & & 10 \\
\hline 3. & Aerial surveys & 1 & 5 & 1 & 1 & 1 & 1 & 9 \\
\hline 4. & Habitat rating system & 1,2 & 2 & & & & & 2 \\
\hline 5. & Remote predator surveillance & 1,2 & 1 & 5 & * & $*$ & * & 6 \\
\hline 6. & Banding & 1,2 & * & * & * & * & * & * \\
\hline \multirow[t]{2}{*}{7.} & \multirow[t]{2}{*}{ Cooperate with other initiatives } & \multirow[t]{2}{*}{ All } & * & * & $*$ & * & * & * \\
\hline & & & 33 & 41 & 26 & 26 & 26 & 152 \\
\hline 8.5 & $\begin{array}{l}\text { Plan Management \& } \\
\text { Administration }\end{array}$ & & & & & & & \\
\hline 1. & Annual recovery team meeting & All & 1 & 1 & 1 & 1 & 1 & 5 \\
\hline 2. & Evaluate recovery actions & All & * & * & * & * & * & * \\
\hline 3. & Liaison with other plover initiatives & 1 & * & * & * & * & * & * \\
\hline 4. & Database management & 1 & 4 & 4 & 4 & 4 & 4 & 20 \\
\hline \multirow[t]{3}{*}{5.} & Annual report & 1 & 1 & 1 & 1 & 1 & 1 & 5 \\
\hline & \multirow[t]{2}{*}{ Overall Coordination } & \multirow[t]{2}{*}{1} & 18 & 18 & 18 & 18 & 18 & 90 \\
\hline & & & 24 & 24 & 24 & 24 & 24 & 120 \\
\hline 8.6 & Resource Acquisition & & & & & & & \\
\hline 1. & Funding securement & 1,2 & 5 & 5 & 5 & 5 & 5 & 25 \\
\hline \multirow[t]{2}{*}{2.} & \multirow[t]{2}{*}{ Staff training } & \multirow[t]{2}{*}{1,2} & 2 & 2 & 2 & 2 & 2 & 10 \\
\hline & & & 7 & 7 & 7 & 7 & 7 & 35 \\
\hline & TOTAL & & 182 & 190 & 175 & 175 & 175 & 897 \\
\hline
\end{tabular}

${ }^{1}$ Alberta Fish and Wildlife Division, ${ }^{2}$ Alberta Conservation Association 


\subsection{SOCIO-ECONOMIC CONSIDERATIONS}

It is a guiding principle of the Alberta Piping Plover Recovery Team that landowners and leaseholders should not be unduly affected by costs associated with implementation of the plan (see Section 7.2). However, potential economic costs affecting landholders and industrial developers may include occasional restrictions on land-use activities, or on timing of these activities. Restrictions on use or timing of shorelines for recreational activities could impact cottagers or tourists, but it is unlikely that complete restriction of beaches would be needed. A potential economic benefit for leaseholders and landowners is increased productivity of their lands (e.g., for grazing) following habitat management activities aimed at improving habitat for piping plovers. In addition, conservation and stewardship of lakeshore habitat for piping plovers will benefit a variety of other wildlife species and may increase biodiversity in these areas.

There is considerable public interest in piping plovers, making this an ideal species for increasing public awareness and support for the conservation of other at risk wildlife and wildlife habitats. Plovers are considered a priority species for birdwatchers (Goossen et al. 2002). Recreational viewing (birdwatching) has high social value and also has economic value in terms of its potential for ecotourism.

\subsection{PLAN REVIEW AND AMENDMENT}

The life of this plan is five years. The Alberta Piping Plover Recovery Team will conduct an annual review of the plan to monitor the implementation of the plan and to determine the effectiveness of recovery actions. A report on the results of these reviews will be submitted annually to the Director of Wildlife Management. Recovery action plans are considered "living" documents and recovery actions can be amended during these reviews as new information becomes available, conditions change, or circumstances warrant. At the end of five years, the recovery team will meet again to determine whether any other amendments are required, prior to the plan being renewed for another five years. The team may determine that the existing recovery plan is suitable or is in need of revision. 


\subsection{REFERENCES}

Achuff, P. L. 1994. Natural regions, subregions and natural history themes of Alberta - a classification for protected areas management, revised and updated December 1994. Alberta Environmental Protection, Edmonton, AB. 114 pp.

Alberta Fish and Wildlife Division. 1991. Management plan for the piping plover in Alberta (final draft). Alberta Fish and Wildlife Division, Edmonton, AB. 67 pp.

Alberta Fish and Wildlife Division. 2001. Protection of selected wildlife species and habitat within Grassland and Parkland Natural Regions of Alberta. Alberta Fish and Wildlife Division, Edmonton, AB. 5 pp. (available at http://www3.gov.ab.ca/srd/fw/landuse/index.html).

Anonymous. 2005. Species at Risk Act policy. (Draft) policy on the feasibility of recovery (06/01/2005). Environment Canada, Ottawa, ON. 4 pp.

Alberta Piping Plover Recovery Team. 2002. Alberta Piping Plover Recovery Plan, 2002-2004. Alberta Sustainable Resource Development, Fish and Wildlife Division, Alberta Species at Risk Report Recovery Plan No. 2, Edmonton, AB. 21 pp.

Alberta Piping Plover Recovery Team. 2005. Implementation of the Alberta Piping Plover Recovery Plan, 2002-2004: Final program report. Alberta Sustainable Resource Development, Fish and Wildlife Division, Alberta Species at Risk Report No. 99, Edmonton, AB. 19 pp.

Bjorge, R. R. 1997. The 1996 piping plover census in Alberta. Pp. 158-163 in 1996 International piping plover census (J. H. Plissner and S.M. Haig, eds.). Report to U.S. Geological Survey, Biological Resources Division, Forest and Rangeland Ecosystem Science Center, Corvallis, Oregon. 231 pp.

Bjorge, R. R., and A. J. Murphy. 2004. The 1996 piping plover census in Alberta. Pp. 117-139 in The 1996 International Piping Plover Census in Canada (J.P. Goossen and D. L. Amirault, eds.). Canadian Wildlife Service, Technical Report Series No 416, Edmonton, AB and Sackville, NB. 164 pp.

Bottitta, G. E., A. M. Cole, and B. Lapin. 1997. Piping plovers produce two broods. Wilson Bulletin 109:337-339.

Cairns, W. E. 1982. Biology and behavior of breeding piping plovers. Wilson Bulletin 94:531545.

Canadian Permanent Committee on Geographic Names. 1988. Gazetteer of Canada: Alberta, $3^{\text {rd }}$ edition. Department of Energy, Mines and Resources, Ottawa, ON. 64 pp.

COSEWIC. 2005. Canadian species at risk. Committee on the Status of Endangered Wildlife in Canada, Ottawa, ON. (available at http://www.cosewic.gc.ca/eng/sct0/rpt/rpt_csar_e.cfm). 
Engley, L. 2001. Use of predator exclosures to protect Piping Plover nests in Alberta and Saskatchewan: 2001 field season report. Unpubl. rept., Alberta Conservation Association, Edmonton, AB. 17pp.

Engley, L., and D. R. C. Prescott. 2004. Alberta piping plover predator exclosure and population monitoring program. Pp. 12-14 in Westworth, S.M, D. Martens, C.L. GrattoTrevor, J. P. Gooseen and S. Davis (eds.) Northern Great Plains Piping Plover Science Workshop, November 2003, Regina, Saskatchewan.

Engley, L., D. Prescott, and R. Schmelzeisen. 2004. Alberta piping plover predator exclosure and population monitoring program. 2004 field season report. Alberta Conservation Association, Edmonton, AB. 29 pp.

Engley, L., and R. Schmelzeisen. 2002. Alberta piping plover predator exclosure and population monitoring program. 2002 field season report. Alberta Conservation Association, Edmonton, AB. 22pp.

Espie, R. H. M., R. M. Brigham, and P. C. James. 1992. Breeding ecology of the piping plover at Lake Diefenbaker, Saskatchewan. Unpublished report for Canadian Wildlife Service, Edmonton, AB. 31 pp.

Ferland, C. L., and S. M. Haig. 2002. 2001 International Piping Plover Census. U.S. Geological Survey, Forest and Rangeland Ecosystem Science Center, Corvallis, WA. 293 pp.

Flemming, S. P., R. D. Chiasson, P. C. Smith, P. J. Austin-Smith, and R. P. Bancroft. 1988. Piping plover in Nova Scotia related to its reproductive and behavioural responses to human disturbance. Journal of Field Ornithology 59:321-330.

Goossen, J. P. 1989. Prairie piping plover conservation: first annual report (1988). Unpublished report, Canadian Wildlife Service, Edmonton, AB. 19 pp.

Goossen, J. P. 1994. Prairie piping plover conservation: 1992 and 1993. Unpublished draft report, Canadian Wildlife Service, Edmonton, AB. 34 pp.

Goossen, J. P., D. L. Amirault, S. Richard, R. Bjorge, J. Brazil, S. Brechtel, R. Chiasson, G. N. Corbett, F. R. Curley, M. Elderkin, S. P. Flemming, W. Harris, L. Heyens, D. Hjertaas, M. Huot, R. Jones, W. Koonz, P. Laporte, R. I. G. Morrison, C. Stewart, L. Swanson and E. Wiltse. 2002. National recovery plan for piping plover (Charadrius melodus). National Recovery Plan No. 22. Recovery of Nationally Endangered Wildlife. Ottawa, ON. 47 pp.

Goossen, J. P., S. M. Westworth, B. Yee, D. Thorson, and I. Michaud. 2000. Atlas of piping plovers in the Canadian Prairie Provinces and Ontario. Multimedia CD-ROM atlas produced by Environment Canada, Edmonton and Regina. 
Haig, S. M. 1985. Updated status report on the piping plover Charadrius melodus in Canada. Committee on the Status of Endangered Wildlife in Canada, Ottawa, ON. 23 pp.

Haig, S. M. 1992. Piping plover. In The Birds of North America, No. 2 (A. Poole, P. Stettenheim and F. Gill, eds.). The Academy of Natural Sciences, Philadelphia, PA, and The American Ornithologists' Union, Washington, DC. 18 pp.

Haig, S. M., W. Harrison, R. Lock, L. Pfannmuller, E. Pike, M. Ryan, and J. Sidle. 1988. Recovery plan for piping plovers (Charadrius melodus) of the Great Lakes and northern Great Plains. U. S. Fish and Wildlife Service, Twin Cities, MN. 160 pp.

Haig, S. M., and L. W. Oring. 1988a. Mate, site, and territory fidelity in piping plovers. Auk 105:268-277.

Haig, S. M., and L. W. Oring. 1988b. Distribution and dispersal in the piping plover. Auk 105:630-638.

Heckbert, M. D. 1994. Piping plover (Charadrius melodus) ecology and conservation in Alberta (1994): Reflex Lake and Killarney Lake field report. Unpublished report, Alberta Fish and Wildlife Services, Vermilion, AB. $152 \mathrm{pp}$.

Heckbert, M. D., and K. D. Cantelon. 1996. Piping plover (Charadrius melodus) ecology and conservation in Alberta (1995): east-central Alberta field report. Unpublished report for Natural Resources Service and Alberta NAWMP Centre, Edmonton, AB. 163 pp.

Hofman, D. E. 1992. 1992 piping plover survey, Little Fish Lake, Alberta. Unpublished report, Alberta Fish and Wildlife Division, Red Deer, AB. 16 pp.

Hofman, D. E. 1994. The 1991 piping plover census in Alberta. Pp. 43-47 in The 1991 International Piping Plover Census in Canada (S. P. Flemming, ed.). Canadian Wildlife Service Occasional Paper No. 82.59 pp.

Ivan, J. S., and R. K. Murphy. 2005. What preys on piping plover eggs and chicks? Wildlife Society Bulletin 33:113-119.

Jung, T. S., J. P. Goossen, B. Aitken, and I. A. Bisson. 1998. Conservation biology of piping plovers at Lake Diefenbaker, Saskatchewan: 1997 progress report. Unpublished report, Canadian Wildlife Service, Edmonton, AB. 49 pp. + appendices.

Larson, M. A., M. R. Ryan, and B. G. Root. 2000. Piping plover survival in the Great Plains: an updated analysis. Journal of Field Ornithology 71:721-729.

Martens, D. C., and J. P. Goossen. In prep. National Recovery Strategy for the Piping Plover (Charadrius melodus circumcinctus). Prepared for the Prairie Piping Plover Recovery Team. 
Michaud, I., and D. Prescott. 1999. Use of predator exclosures to protect piping plover nests in Alberta and Saskatchewan: 1999 field season report. Alberta Conservation Association, Edmonton, AB. 9 pp. + appendices.

Murphy, R. K., I. M. G. Michaud, D. R. C. Prescott, J. S. Ivan, B. J. Anderson, and M. L. French-Pombier. 2003. Predation on adult piping plovers at predator exclosure cages. Waterbirds 26:150-155.

Murphy, R. K., B. G. Root, P. M. Mayer, J. P. Goossen and K. A. Smith. 1999. A draft protocol for assessing piping plover reproductive success on Great Plains alkali lakes. Pp. 90-107 in K. F. Higgins, M.R. Brashier and C. D. Kruse (eds.), Proceedings, Piping Plovers and Least Terns of the Great Plains and nearby. Brooking: South Dakota State University. 132 pp.

Murphy, R. K., M. L. Sondreal, D. A. Guenther, and M. P. Nenneman. 1995. Reproductive success of piping plovers on alkali lakes in northwestern North Dakota. Pp. 13-21 in Conservation of piping plovers in northwestern North Dakota. 1995 annual report. 19 pp. + appendices.

Pinel, H. W., W. W. Smith, and C. R. Wershler. 1991. Alberta birds, 1971-1980. Provincial Museum of Alberta, Natural History Occasional Paper No. 13, Edmonton, AB. 243 pp.

Plissner, J. H., and S. M. Haig. 1997. 1996 International Piping Plover Census. U.S. Geological Survey, Biological Resources Division, Forest and Rangeland Ecosystem Science Center, Corvallis, OR. $231 \mathrm{pp}$.

Plissner, J. H., and S. M. Haig. 2000. Viability of piping plover Charadrius melodus metapopulations. Biological Conservation 92:163-173.

Prescott, D. R. C. 1997. Status of the piping plover (Charadrius melodus) in Alberta. Alberta Environmental Protection, Wildlife Management Division, Wildlife Status Report No. 1, Edmonton, AB. 19 pp.

Prescott, D. R. C. 2001a. Aerial reconnaissance surveys for piping plover habitat in east-central Alberta, May 2001. Alberta Sustainable Resource Development, Fish and Wildlife Division, Alberta Species at Risk Report No. 26, Edmonton, AB. 10 pp.

Prescott, D. R. C. 2001b. The 2001 International Piping Plover Census in Alberta. Alberta Sustainable Resource Development, Fish and Wildlife Division, Alberta Species at Risk Report No. 27, Edmonton, AB. 15 pp.

Prescott, D. R. C. 2004. The role of habitat: is it a limiting factor on the breeding grounds? Pp. 6-8 in Northern Great Plains Piping Plover Science Workshop, November 2003 (S.M. Westworth, D. Martens, C.L. Gratto-Trevor, J. P. Goossen and S. Davis, eds.). Canadian Wildlife Service, Regina, SK. 60 pp. 
Prescott, D. R. C., and L. Engley. In prep. Productivity of piping plovers in Alberta, 1994-2004. Alberta Sustainable Resource Development, Species at Risk Report.

Prindiville Gaines, E., and M. R. Ryan. 1988. Piping plover habitat use and reproductive success in North Dakota. Journal of Wildlife Management 52:266-273.

Richardson, I. M. 1999. Predator exclosures: a management technique to increase piping plover (Charadrius melodus) reproductive success in the Canadian prairies. M.Sc. thesis, University of Alberta, Edmonton, AB. 65 pp.

Root, B. G., M. R. Ryan, and P. M. Mayer. 1992. Piping plover survival in the Great Plains. Journal of Field Ornithology 63:10-15.

Ryan, M. R., B. G. Root, and P. M. Mayer. 1993. Status of piping plovers in the Great Plains of North America: a demographic simulation model. Conservation Biology 7:581-585.

Schmelzeisen, R., and L. Engley. 2003. Alberta piping plover predator exclosure and population monitoring program. 2003 field season report. Unpublished Report. Alberta Conservation Association, Edmonton, AB. 26pp.

Schmelzeisen, R., D. R. C. Prescott, and L. Engley. 2004. Methods for controlling depredation on piping plovers in Alberta: a literature review and synthesis. Alberta Sustainable Resource Development, Fish and Wildlife Division, Alberta Species at Risk Report No. 84, Edmonton, AB. 24 pp.

Wershler, C. R. 1992. An analysis of piping plover management concerns in Alberta. Unpublished report for Alberta NAWMP Centre, Edmonton, AB. 56 pp.

Wershler, C., and C. Wallis. 1987. Status of the piping plover in Alberta, 1986. Unpublished report for World Wildlife Fund Canada and Canadian Wildlife Service, Calgary, AB. 54 $\mathrm{pp}$.

Westworth, S. M., D. Martens, C. L. Gratto-Trevor, J. P. Goossen, and S. Davis. 2004. Northern Great Plains Piping Plover Science Workshop, November 2003, Regina, SK. 60 $\mathrm{pp}$.

Whyte, A. J. 1985. Breeding biology of the piping plover (Charadrius melodus) in central Saskatchewan. M.Sc. thesis, University of Saskatchewan, Saskatoon, SK. 53 pp. 


\subsection{APPENDICES}

Appendix 1. Waterbodies known to have supported piping plovers in Alberta (see Appendix 2 for map). Sources: Wershler and Wallis (1986), Hofman (1994), Bjorge (1997), Prescott (1997), Goossen et al. (2000), Prescott (2001b), Engley (2001), Engley and Schmelzeisen (2002), Schmelzeisen and Engley (2003), Engley et al. (2004).

\begin{tabular}{|c|c|c|c|c|c|c|c|}
\hline $\begin{array}{c}\text { Map } \\
\#\end{array}$ & Waterbody $^{1}$ & \begin{tabular}{|c|} 
\# Years \\
Surveyed
\end{tabular} & $\begin{array}{l}\text { \#Years } \\
\text { Present }\end{array}$ & $\begin{array}{c}\text { Population } \\
\text { Size }\end{array}$ & $\begin{array}{l}\text { Breeding } \\
\text { Confirmed }\end{array}$ & $\begin{array}{c}\text { Latitude } \\
\left({ }^{\circ} \mathrm{N}\right)\end{array}$ & $\begin{array}{l}\text { Longitude } \\
\left({ }^{\circ} \mathrm{W}\right)\end{array}$ \\
\hline 1 & Akasu & 9 & 6 & $2-10$ & $\mathrm{Y}$ & 53.50 & 111.02 \\
\hline 2 & Albert & 5 & 2 & $2-6$ & $\mathrm{Y}$ & 53.17 & 110.45 \\
\hline 3 & Baxter & 12 & 10 & $2-8$ & $\mathrm{Y}$ & 52.94 & 110.73 \\
\hline 4 & Beaverhill & 17 & 15 & $1-13$ & $\mathrm{Y}$ & 53.45 & 112.53 \\
\hline 5 & Birch & 12 & 11 & $2-14$ & $\mathrm{Y}$ & 53.32 & 111.59 \\
\hline 6 & Bittern & 5 & 2 & 2 & $\mathrm{Y}$ & 53.05 & 113.08 \\
\hline 7 & Blood Indian Reservoir & 1 & 1 & 1 & $\mathrm{~N}$ & 51.25 & 111.22 \\
\hline 8 & Border & 1 & 1 & 2 & $\mathrm{Y}$ & 52.62 & 110.72 \\
\hline 9 & Bow River/Carseland Prov. Park & 1 & 1 & 7 & $\mathrm{~N}$ & 50.83 & 113.43 \\
\hline 10 & Buffalo & 14 & 9 & $1-20$ & $\mathrm{Y}$ & 52.45 & 112.90 \\
\hline 11 & Chain "\#1" (Pearl) & 9 & 5 & $1-4$ & $\mathrm{Y}$ & 51.77 & 112.10 \\
\hline 12 & Chain “\#3” (Clear) & 7 & 4 & $1-2$ & $\mathrm{Y}$ & 51.79 & 112.13 \\
\hline 13 & Chain "\#4" & 19 & 19 & $1-24$ & $\mathrm{Y}$ & 51.80 & 112.15 \\
\hline 14 & Chain "\#6" & 4 & 1 & 2 & $\mathrm{Y}$ & 51.84 & 112.18 \\
\hline 15 & Chappice & 22 & 15 & $1-17$ & $\mathrm{Y}$ & 50.15 & 110.35 \\
\hline 16 & Chestermere & 3 & 1 & 1 & $\mathrm{~N}$ & 51.03 & 113.82 \\
\hline 17 & Cipher & 15 & 15 & $1-4$ & $\mathrm{Y}$ & 52.68 & 110.10 \\
\hline 18 & Clark & 1 & 1 & 8 & $\mathrm{Y}$ & 52.27 & 110.75 \\
\hline 19 & Cochrane & 3 & 1 & 1 & $\mathrm{~N}$ & 51.25 & 114.48 \\
\hline 20 & Dalemead & 1 & 1 & 2 & $\mathrm{~N}$ & 50.92 & 113.62 \\
\hline 21 & Dawson & 1 & 1 & 1 & $\mathrm{~N}$ & 51.13 & 113.40 \\
\hline 22 & Dillberry & 5 & 1 & 3 & $\mathrm{~N}$ & 52.58 & 110.00 \\
\hline 23 & Dowling & 20 & 20 & $2-58$ & $\mathrm{Y}$ & 51.73 & 112.01 \\
\hline 24 & Eagle & 3 & 1 & 1 & $\mathrm{~N}$ & 51.00 & 113.32 \\
\hline 25 & "Foster" & 10 & 7 & $2-6$ & $\mathrm{Y}$ & 52.23 & 110.55 \\
\hline 26 & Frank & 4 & 2 & 3 & $\mathrm{Y}$ & 50.57 & 113.72 \\
\hline 27 & Frog & 4 & 4 & $3-9$ & $\mathrm{Y}$ & 53.92 & 110.33 \\
\hline 28 & Gillespie & 6 & 1 & 2 & $\mathrm{~N}$ & 52.42 & 110.18 \\
\hline 29 & Gooseberry & 12 & 10 & $1-9$ & $\mathrm{Y}$ & 52.12 & 110.73 \\
\hline 30 & Goosequill & 7 & 2 & 2 & $\mathrm{Y}$ & 52.05 & 113.15 \\
\hline 31 & "Greenlee" & 8 & 6 & $1-4$ & $\mathrm{Y}$ & 52.22 & 110.48 \\
\hline 32 & Gull & 5 & 4 & $1-6$ & $\mathrm{~N}$ & 52.57 & 114.00 \\
\hline 33 & Handhills & 20 & 20 & $2-82$ & $\mathrm{Y}$ & 51.49 & 112.12 \\
\hline 34 & Hansman & 4 & 3 & $1-6$ & $\mathrm{Y}$ & 52.39 & 110.39 \\
\hline 35 & Hattie & 2 & 1 & 1 & $\mathrm{~N}$ & 52.98 & 111.57 \\
\hline 36 & Horseshoe & 8 & 5 & $2-8$ & $\mathrm{Y}$ & 52.36 & 110.74 \\
\hline 37 & "Janet" & 3 & 1 & 1 & $\mathrm{~N}$ & 51.02 & 113.87 \\
\hline 38 & "Junction" & 4 & 1 & 2 & $\mathrm{Y}$ & 53.45 & 111.75 \\
\hline 39 & Keho & 8 & 6 & $1-4$ & $\mathrm{Y}$ & 49.95 & 112.98 \\
\hline 40 & Killarney & 16 & 14 & $1-48$ & $\mathrm{Y}$ & 52.58 & 110.10 \\
\hline 41 & Leane & 10 & 5 & $1-2$ & $\mathrm{Y}$ & 52.56 & 110.07 \\
\hline 42 & Lesser Slave & 3 & 1 & 1 & $\mathrm{~N}$ & 55.45 & 115.45 \\
\hline 43 & Little Fish & 22 & 17 & $1-48$ & $\mathrm{Y}$ & 51.37 & 112.22 \\
\hline
\end{tabular}




\begin{tabular}{|c|c|c|c|c|c|c|c|}
\hline $\begin{array}{c}\text { Map } \\
\#\end{array}$ & Waterbody $^{1}$ & \begin{tabular}{|c|} 
\# Years \\
Surveyed
\end{tabular} & $\begin{array}{l}\text { \# Years } \\
\text { Present }\end{array}$ & $\begin{array}{c}\text { Population } \\
\text { Size }\end{array}$ & $\begin{array}{c}\text { Breeding } \\
\text { Confirmed }\end{array}$ & $\begin{array}{c}\text { Latitude } \\
\left({ }^{\circ} \mathrm{N}\right)\end{array}$ & $\begin{array}{c}\text { Longitude } \\
\left({ }^{\circ} \mathrm{W}\right)\end{array}$ \\
\hline 44 & Long & 2 & 1 & 1 & $\mathrm{~N}$ & 51.22 & 113.42 \\
\hline 45 & Lowden & 6 & 1 & unknown & $\mathrm{N}$ & 52.15 & 112.70 \\
\hline 46 & McDonald & 6 & 2 & $2-3$ & $\mathrm{~N}$ & 51.20 & 113.94 \\
\hline 47 & McGregor & 5 & 2 & $1-2$ & $\mathrm{Y}$ & 50.42 & 112.87 \\
\hline 48 & "McLaren" & 4 & 4 & $1-5$ & $\mathrm{Y}$ & 52.29 & 110.68 \\
\hline 49 & "Metiskow" & 17 & 13 & $1-8$ & $\mathrm{Y}$ & 52.40 & 110.63 \\
\hline 50 & Miquelon "\#1" & 3 & 1 & 1 & $\mathrm{~N}$ & 53.21 & 112.83 \\
\hline 51 & Miquelon "\#2" & 7 & 3 & $3-7$ & $\mathrm{Y}$ & 53.28 & 112.84 \\
\hline 52 & Miquelon "\#3" & 6 & 3 & $1-4$ & $\mathrm{Y}$ & 53.26 & 112.92 \\
\hline 53 & Muriel & 10 & 10 & $2-38$ & $\mathrm{Y}$ & 54.13 & 110.70 \\
\hline 54 & Namaka & 9 & 3 & $2-3$ & $\mathrm{Y}$ & 50.93 & 113.22 \\
\hline 55 & "Neutral Hills A" & 5 & 2 & $2-12$ & $\mathrm{Y}$ & 52.06 & 110.93 \\
\hline 56 & "Neutral Hills B1" & 4 & 2 & $2-4$ & $\mathrm{Y}$ & 52.09 & 110.94 \\
\hline 57 & "Neutral Hills B2" & 5 & 1 & 1 & $\mathrm{~N}$ & 52.10 & 110.97 \\
\hline 58 & "Neutral Hills C1" & 4 & 3 & $5-6$ & $\mathrm{Y}$ & 52.13 & 110.93 \\
\hline 59 & "Neutral Hills C2" & 3 & 1 & 3 & $\mathrm{~N}$ & 52.13 & 110.97 \\
\hline 60 & Newell & 5 & 3 & $1-3$ & $\mathrm{~N}$ & 50.43 & 111.92 \\
\hline 61 & Oliver & 3 & 1 & 2 & $\mathrm{~N}$ & 53.28 & 113.02 \\
\hline 62 & Pakowki & 1 & 1 & 1 & $\mathrm{~N}$ & 49.33 & 110.95 \\
\hline 63 & "Piper" & 12 & 10 & $2-15$ & $\mathrm{Y}$ & 52.33 & 110.63 \\
\hline 64 & Plain & 4 & 1 & 13 & $\mathrm{Y}$ & 53.61 & 111.70 \\
\hline 65 & Plover & 5 & 1 & 6 & $\mathrm{~N}$ & 51.48 & 111.38 \\
\hline 66 & Red Deer & 7 & 6 & $2-10$ & $\mathrm{Y}$ & 52.70 & 113.05 \\
\hline 67 & Reesor & 3 & 1 & 1 & $\mathrm{~N}$ & 49.67 & 110.10 \\
\hline 68 & "Rider" & 15 & 10 & $1-17$ & $\mathrm{Y}$ & 52.52 & 112.77 \\
\hline 69 & Rockeling Bay & 15 & 9 & $2-30$ & $\mathrm{Y}$ & 52.57 & 112.82 \\
\hline 70 & Sam & 8 & 4 & $1-6$ & $\mathrm{Y}$ & 50.15 & 110.25 \\
\hline 71 & Sounding & 7 & 5 & $1-18$ & $\mathrm{Y}$ & 52.13 & 110.48 \\
\hline 72 & South Cooking & 1 & 1 & 2 & $\mathrm{~N}$ & 53.42 & 113.07 \\
\hline 73 & Spiers & 9 & 7 & $1-12$ & $\mathrm{Y}$ & 51.92 & 112.23 \\
\hline 74 & St. Mary Reservoir & 3 & 2 & $2-3$ & $\mathrm{~N}$ & 49.33 & 113.18 \\
\hline 75 & Stirling & 1 & 1 & 1 & $\mathrm{~N}$ & 49.53 & 112.58 \\
\hline 76 & Sunken & 14 & 13 & $2-8$ & $\mathrm{Y}$ & 52.38 & 110.65 \\
\hline 77 & Unnamed (E of Bruce Lake) & 1 & 1 & 1 & $\mathrm{~N}$ & 51.22 & 113.43 \\
\hline 78 & Unnamed (near Keoma) & 1 & 1 & 1 & $\mathrm{~N}$ & 51.23 & 113.58 \\
\hline 79 & Unnamed (near Water Valley) & 1 & 1 & 1 & $\mathrm{~N}$ & 51.50 & 114.60 \\
\hline 80 & Unnamed (E of Sheperd) & 1 & 1 & 1 & $\mathrm{~N}$ & 50.96 & 113.85 \\
\hline 81 & Unnamed (SE of Sam Lake) & 4 & 1 & 1 & $\mathrm{~N}$ & 50.13 & 110.25 \\
\hline 82 & West & 2 & 2 & $2-3$ & $\mathrm{Y}$ & 52.23 & 110.73 \\
\hline 83 & "West" Reflex & 21 & 21 & $12-69$ & $\mathrm{Y}$ & 52.67 & 110.00 \\
\hline 84 & Whitewater & 2 & 1 & 1 & $\mathrm{~N}$ & 52.87 & 111.78 \\
\hline 85 & Whitford & 2 & 1 & 1 & $\mathrm{~N}$ & 53.87 & 112.25 \\
\hline
\end{tabular}

${ }^{1}$ Names of waterbodies not listed by the Canadian Permanent Committee on Geographic Names (1988) are considered to be unofficial names and are listed in quotations. 
Appendix 2. Map of waterbodies where piping plovers have been reported in Alberta. See Appendix 1 for details.

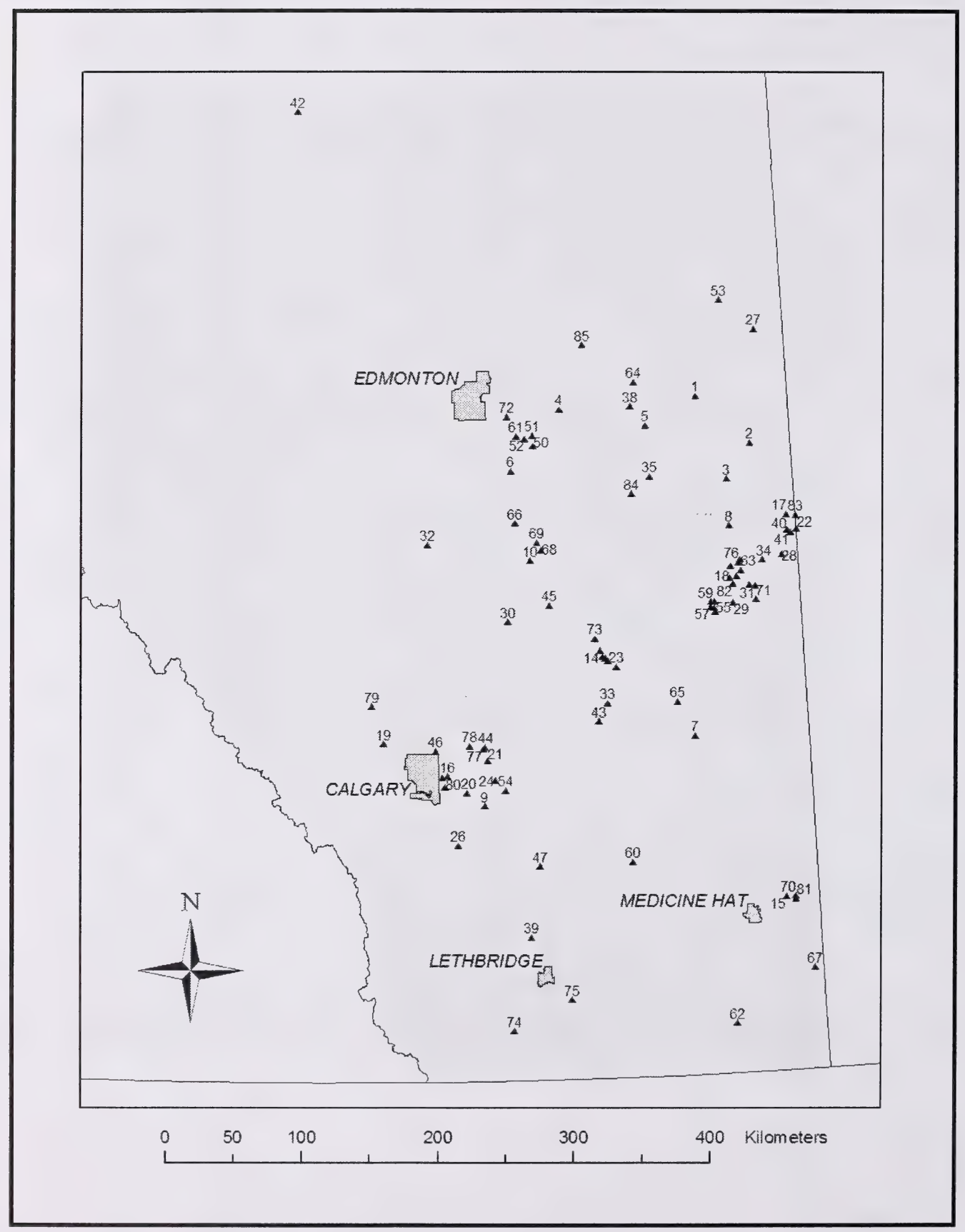


Appendix 3. Critical habitat segments on lakes 13 lakes identified as containing critical habitat in Alberta (see Section 4.1 for criteria). Segments are areas of shoreline between the waterline and the ordinary high water mark, and defined on a quarter-section basis. Specific locations are not given in order minimize disturbance to plovers, and maintain anonymity of adjacent landowners.

\begin{tabular}{|c|c|c|c|}
\hline Lake & Segment & $\begin{array}{l}\text { Shoreline } \\
\text { Ownership }\end{array}$ & $\begin{array}{c}\text { Upland } \\
\text { Ownership }\end{array}$ \\
\hline Akasu & A & Crown & Crown \\
\hline Baxter & A & Crown & Private \\
\hline \multirow[t]{3}{*}{ Birch } & $\mathrm{A}$ & Crown & Crown \\
\hline & $\mathrm{B}$ & Crown & Crown \\
\hline & $\mathrm{C}$ & Crown & Private \\
\hline \multirow[t]{2}{*}{ "Chain \#4" } & $\mathrm{A}$ & Crown & Crown \\
\hline & $\mathrm{B}$ & Crown & Crown \\
\hline \multirow[t]{10}{*}{ Dowling } & $\mathrm{A}$ & Crown & Crown \\
\hline & $\mathrm{B}$ & Crown & Crown \\
\hline & $\mathrm{C}$ & Crown & Private \\
\hline & $\mathrm{D}$ & Crown & Private \\
\hline & $\mathrm{E}$ & Crown & Crown \\
\hline & $\mathrm{F}$ & Crown & Crown/Private \\
\hline & $\mathrm{G}$ & Crown & Crown/Private \\
\hline & $\mathrm{H}$ & Crown & Private \\
\hline & I & Crown & Crown/Private \\
\hline & $\mathrm{J}$ & Crown & Crown/Private \\
\hline \multirow[t]{5}{*}{ Handhills } & A & Crown & Crown/Private \\
\hline & B & Crown & Private \\
\hline & $\mathrm{C}$ & Crown & Crown \\
\hline & $\mathrm{D}$ & Crown & Private \\
\hline & $\mathrm{E}$ & Crown & Crown/Private \\
\hline \multirow[t]{5}{*}{ Killarney } & $\mathrm{A}$ & Crown & Crown \\
\hline & $\mathrm{B}$ & Crown & Crown \\
\hline & $\mathrm{C}$ & Crown & Crown/Private \\
\hline & $\mathrm{D}$ & Crown & Crown \\
\hline & $\mathrm{E}$ & Crown & Crown \\
\hline \multirow[t]{4}{*}{ Little Fish } & $\mathrm{A}$ & Crown & Crown \\
\hline & $\mathrm{B}$ & Crown & Crown \\
\hline & $\mathrm{C}$ & Crown & Crown \\
\hline & $\mathrm{D}$ & Crown & Crown \\
\hline \multirow[t]{3}{*}{ Muriel } & $\mathrm{A}$ & Crown & Crown \\
\hline & $\mathrm{B}$ & Crown & Crown/Private \\
\hline & $\mathrm{C}$ & Crown & Crown \\
\hline \multirow[t]{2}{*}{ Piper } & $\mathrm{A}$ & Crown & Crown/Private \\
\hline & $\mathrm{B}$ & Crown & Crown/Private \\
\hline \multirow[t]{2}{*}{ Red Deer } & $\mathrm{A}$ & Crown & Crown \\
\hline & $\mathrm{B}$ & Crown & Crown \\
\hline Sunken & $\mathrm{A}$ & Crown & Crown/Private \\
\hline \multirow{4}{*}{ West Reflex } & A & Crown & Private \\
\hline & B & Crown & Crown \\
\hline & $\mathrm{C}$ & Crown & Crown/Private \\
\hline & $\mathrm{D}$ & Crown & Crown \\
\hline
\end{tabular}




\section{List of Titles in the Alberta Species at Risk Recovery Plan Series}

(as of March 2006)

No. 1 Maintenance and Recovery Plan for Western Blue Flag (Iris missouriensis) in Canada. (2002)

No. 2 Alberta Piping Plover Recovery Plan 2002-2004. (2002)

No. 3 Alberta Peregrine Falcon Recovery Plan 2004-2010. (2005)

No. 4 Alberta Woodland Caribou Recovery Plan 2004/05-2013/14. (2005)

No. 5. Recovery Plan for Ord's Kangaroo Rat in Alberta. (2005)

No. 6 Recovery Plan for Burrowing Owl in Alberta. (2005)

No. 7 Alberta Northern Leopard Frog Recovery Plan 2005-2010. (2005)

No. 8 Alberta Greater Sage-Grouse Recovery Plan. (2005)

No. 9 Maintenance and Recovery Plan for Western Spiderwort in Alberta 2005-2010. (2005)

No. 10 Alberta Piping Plover Recovery Plan 2005-2010. (2006) 


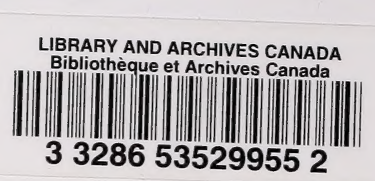

